\title{
Tautos ir nacijos sampratos problema
}

\author{
Paulius Kavaliauskas, \\ Mindaugas Jakutis \\ Vilniaus universitetas, \\ Gamtos mokslu fakultetas, \\ M. K. Čiurlionio g. 21, \\ LT-03101, Vilnius \\ El.paštas: paulius.kaval@gmail.com; \\ mindaugas.jakutis@gf.vu.lt
}

Kavaliauskas P., Jakutis M. Tautos ir nacijos sampratos problema. Geologija. Geografija.2015. T. 1(1). ISSN 2351-7549.

Straipsnyje nagrinëjami politinèje erdvèje, ypač politinèje geografijoje, aktualūs tautos ir nacijos apibréžimai bei šių sąvokų formavimasis angliškoje ir lietuviškoje mokslinèje literatūroje. Pateikiama nagrinejjamų sąvokų problemiškumo geneze, atskirų autorių išskiriamų jas formuojančių veiksnių ir apibūdinančiu požymių analizė. Bandoma išryškinti bendras angliškos ir lietuviškos literatūros tendencijas, taip pat abiejų terminų interpretacijų atskirose kalbinèse terpèse skirtumus.

Remiantis atlikta literatūros šaltinių analize, pateikiami tautos ir nacijos sąvokų apibrèžimai, apjungiantys angliškoje ir lietuviškoje terpèse išaiškintus veiksnius bei požymius. Teigiama, kad neįmanoma visiškai tiksliai apibréžti šių sąvokų vien remiantis pagrindiniais ar papildomais požymiais, nes tai yra politiniai terminai, dažnai orientuoti ir integruoti ị konkrečią politinę sistemą, besiskiriančią savo atsiradimu bei raida, o pastaroji savaip gali interpretuoti šiuos terminus. Kaip perspektyvinè tolesnių tyrimų kryptis politinès geografijos kontekste yra nurodoma užduotis parengti naciju paplitimo pasaulyje žemėlapi ịvertinant pačių naciju išsivystymo laipsnị.

Raktažodžiai: tauta, nacija, savimonè, nacionalizmas, solidarumas, valstybė

\section{IVADAS}

Pastaraisiais dešimtmečiais vykstant ịvairiems politiniams ir globaliems procesams vis dažniau mokslinejje literatūroje galima rasti įvairių autorių straipsnių ir knygų, kuriuose aptariami terminai - tauta, nacija, apibūdinantys ịvairius politinius-teritorinius darinius. Minèti žodžiai dažniausiai vartojami kaip sinonimai, kai vienas ar kitas terminas tekste paprastai išreiškia autoriaus simpatiją vienam ar kitam terminui. Ypač sudètinga situacija yra vakarietiškoje spaudoje, kur su nedideliais galūnès skirtumais įvairiose germaniškose ar romaniškose kalbose tautą ir naciją (pagal mūsų sampratą) atitinka žodis nation. Jis kilęs iš lotyniško žodžio natio, traktuojamo kaip giminè, tautybė, klasė, nacija, tauta, būrys, rūšis, kasta, veislè, luomas (Kuzavinis, 2007) ar net padermè (Jokantas, 1995). Dèl tokio daugiaprasmiškumo tampa neaiš$\mathrm{ku}$, ar kalbama apie tauta ir nacija politine prasme, ar dar apie kažką kitą.
Europoje žodis nation buvo perimtas iš senosios prancūzų kalbos dar renesanso laikais. I prancūzų kalbą terminas nation atejjo iš lotyniško žodžio nas$c i$, kuris reiške gimti, o pats nation to meto prancūzu kalboje buvo siejamos su proteviais, gimtine ar sava kultūra (Cresswell, 2010). Nors kitose kalbose tauta ir nacija igavo dvi skirtingas prasmes, bet angliškame variante susiformavo tradicija terminu nation sujungti abi sąvokas. Šio termino lietuviškas vertimas iš angliškos literatūros taip pat nusakytų tautos ir nacijos reikšmes vienu žodžiu (Jokantas, 1995; Kuzavinis, 2007). Stiprios anglų kalbos ir jos literatūros pozicijos globalioje visuomenèje neišvengiamai lèmé tam tikrą sumaištị kitose kalbose suprantant ir vartojant žodžius tauta ir nacija.

Pažymètina, kad dabartiniuose lietuvių autorių darbuose (Aramavičiutè, 2008; Butkus, 2009; Kundratas, 2009; Savoniakaitè, 2011 ir kt.) dažniausiai aptinkama sąvoka tauta, o nacija vartojama rečiau, paprastai tik žodynuose ar vieno kito autoriaus darbuose (Gineika, Letukienė, 2008; Daukšas, 2010). 
Vis dèlto abi sąvokos apibūdinamos panašiai, nors ir ne visada lieka aišku, ar kalbama apie tą patį tyrimo objektą, ar tiesiog vartojamos sąvokos savo nuožiūra. Kitų šalių autoriai (Jaher, 2003; Baycroft, Hewitson, 2006; Reill, 2012 ir kt.) žodį nation dažniausiai sieja su konkrečių savybių (bendra kalba, kultūra ir kt.), o ne su pačios politinès organizacijos išskyrimu, nors žodynuose labiau akcentuojamas (Barber, 2004; Deverson, Kennedy, 2005; Bjork..., 2010 ir kt.) šio termino ryšys su valstybingumu.

Straipsnio tikslas - išaiškinti tautos ir nacijos terminu politologinio ir teritorinio problemiškumo priežastis, jų bendrąsias sąsajas ir skirtumus. Teko sutelkti dèmesị ne tik ị šių terminų sąsajų ir skirtumų paiešką dabartinių autorių naudojamose interpretacijose, bet ir î pačių terminų lingvistinę evoliuciją. Suprasdami, kad vienas ar kitas terminijos neaiškumas veda ị tarpusavio nesusikalbejjimus ir nesusipratimus, autoriai pabande šiuo straipsniu supažindinti skaitytoją su esamomis politologinèmis ir politinèmis geografinèmis tendencijomis, pateikti konstruktyvesni šios terminologinès problemos sprendimą. Tai neabejotinai svarbu politinès geografijos raidai mūsų šalyje.

\section{TAUTOS IR NACIJOS SĄVOKŲ BENDROJI PROBLEMATIKA}

Tautos ar nacijos sąvokų vartojimas, tiksliai neapibrèžiant šių terminų vartojimo galimybių literatūros kontekstuose, yra pastebimas tiek Lietuvoje, tiek ir už jos ribų. Žodis nacija Europos kalbose yra invazinis, atèjęs ị lietuvių kalbą (ir ị kitas kalbas) kaip tarptautinis žodis, jis nèra suformuotas savaiminių, lingvistinių procesų atskirose šalyse ar regionuose. Tai atskleidžia ir nacijos sąvoka skirtingose kalbose: bulgariškai нация, daniškai nation, ispaniškai nacion, itališkai nazione, olandiškai natie, rumuniškai națiune, rusiškai нация, švediškai nation, vokiškai nation ir t. t., kai tautos sąvoka kiekvienoje iš šių kalbų skiriasi.

Pats žodis tauta yra labai senas indoeuropietiškas žodis teuta, vartotas Vidurio Europoje apibūdinant stambius, besiformuojančius teritorinius darinius ar labai didelę žmonių grupę (Ambrazas, 2006) ankstyvaisiais viduramžiais. Dar senesnị tautos, kaip žodžio, vartojimą galima sieti su baltų tauto, germanų tiuda, oskų touto, umbrų tota, ilyrų teut ar keltų tuath (Ambrazas, 2006). Tokiu atveju svarstyti tautos, kaip žodžio, nebuvimą ar antraeiliškumą yra beprasmis darbas, nes jis nuo seniausių laikų savaime yra gyvųjų baltų (latvių, lietuvių) kalbų sudetyje. Šiuo atveju reikètų aptarti tik pačios tautos, kaip sąvokos, apibrèžimą.

Nacija, palyginti su tauta, yra jauna sąvoka. Minètas termino nation dviprasmiškumas anglu kalboje, peremus jị iš prancūzų kalbos, pradžioje, matyt, nebuvo visuotinai išreikštas. XVI-XVIII a. nation galèjo būti vartojamas kaip sinonimas kartu su kitais panašias reikšmes turinčiais angliškais žodžiais people ar populus ir turejo apibūdinti maždaug tą patị, kaip ir tautos sąvoka tuometinèse prancūzų, italų ar kitose kalbose. Pagrindinis nation vartojimo lūžis įvyko XVIIIXIX a., kai pradedant Didžiąja Prancūzijos revoliucija ir kitais dešimtmečiais plintant jos idejoms i i ivairius Europos kraštus, buvo pradèta apmąstyti tada labiau prancūzišką nei anglišką nation sąvoką ir jos reikšmę (Kuzmickas, 2013). Šią idèją ypač kèlè prancūzų, o paskui ir anglų filosofai (Smith, 1994). Iš prancūziško žodžio nation kilo kitas prancūziškos kilmès terminas nacionalizmas (pran. nationalisme) (Gineika, Letukienè, 2008). Abi šios sąvokos, tiek nacija, tiek ir nacionalizmas, buvo gretinamos su politiniais ir ideologiniais teritorinių bendruomenių interesais, o ne su bendrų požymių išskyrimu, kurie būdingi vieningai ir organizuotai žmonių bendruomenei. Tokiomis aplinkybėmis Prancūzijoje susiformavo prancūziškoji (palaipsniui virtusi bendravakarietiškąja) paradigma. Ji teigia, kad nacijas (kurių ideologinè ideja kyla iš nacionalizmo) pirmiausiai formuoja pačios valstybès, o ne žmonès ar tauta (Kuzmickas, 2013).

Remiantis šia paradigma, tauta ir tautiškumas suprantamos kaip sąvokos, apibūdinančios žemesnio rango politinius ir teritorinius darinius, dažniausiai priklausančius nuo viršesnio politinio darinio ar esančius jų sudètyje. Taip įvairiose tautu kalbose įsitvirtinusi tautos sąvoka buvo po truputi stumiama $\mathfrak{i}$ politikos periferiją ir pasitelkiama tradiciniams tipologiniams žmonių bendrijų požymiams apibūdinti, bet ne tuometinèms visuomeninèms politinèms naujovèms. Prancūzijoje suformuotas ir filosofiškai bei politiškai plètotas nacijos sąvokos supratimas, jos atskyrimas nuo tautos supratimo ir galimas pritaikymas vartojamoje kalboje, palyginti greitai buvo pritaikytas net angliškoje lingvistikoje. Esantys gerokai senesni 
žodžiai people ar popule (apibūdinantys to meto tautą) buvo nustumti i šoną kaip atgyvena, o vietoj jų ísitvirtino naujas ir kartu politini dviprasmiškumą išreiškiantis terminas nation, kuris dar iki XIX a. simbolizavo tautinị darinį.

Taigi, angliškas žodis nation šiuo metu yra dviprasmiškas terminas, kurio pagrindinè reikšmè būtų nacija (labiau siejama su valstybingumu), o antrinè - tauta (labiau siejama su etniškumu). Ši dviprasmiškumą galima rasti anglakalbių šalių kalbų žodynuose (Barber, 2004; Deverson, Kennedy, 2005; Bjork..., 2010 ir kt.), kuriuose natio labiau siejamas su valstybingumu (kartu ir su nacijos supratimu), nei siekiant išskirti bendrus, būdingus sudètingoms ar teritorinèms bendruomenèms, bruožus. Vis deltto dalis anglosaksų autorių (Smith, 1999; Baycroft, Hewitson, 2006 ir kt.), rašančių istorine ar politine tematika, terminą natio labiau sieja su bendrų bruožų išskyrimu, o ne su valstybingumu.

Pirmoji samprata būdinga jau minètai prancūziškajai paradigmai, kurioje terminai nation ir perssones (pranc. tauta) yra aiškiai atskirti, nes antrosios sąvokos apibrèžime nèra savimonès ir valstybingumo. Antruoju atveju nesiejamas terminas nation su valstybingumu yra būdingas vokiškajai paradigmai (Kuzmickas, 2013), kurioje šis žodis (pagal sąvokų supratimą) yra pakankamai artimas tautai (vok. Volk). Skiriamasis bruožas tarp Volk ir nation - gilesnè organizacinè savimonè nation apibrèžime. Galima teigti, kad kalbant apie tauta labiau tiktų remtis vokiškąja Volk versija, pakankamai artima lietuviškai tautos sampratai.

Pažymètina, kad nors terminas nation ir reiškia nacija, bet savo pirmapradi tautos suvokimą dar išlaiko kaip antraeilę sąvokos reikšmę, dabar suteikiančią dviprasmiškumą. Kai anglų kalba tapo tarptautine, dviprasmiškumo tendencija išplito po visą pasauli, atnešdama ne tik naują sąvoką, bet kartu ir jos suvokimo problemiškumą.

Tautos ir nacijos sąvoku sampratos ypatumai bei skirtumai buvo aptarti ir anksčiau publikuotame P. Kavaliausko ir J. Prunskytès straipsnyje (2012), kuriame konstatuojama, kad nèra standartizuotų ir neginčytinų šių terminų apibrežimų, nes žvelgiant iš įvairių pozicijų teikiami apibrèžimai igauna skirtingas reikšmes ir kelia daug diskusijų. Straipsnyje buvo priminta ir sovietmečiu gana aiškiai trijų pakopų sistemoje suformuota sąvokų triada: a) „nacija“ (нация), b) „tauta“ (народ) ir c) „etninè grupe““ (этническая группа, народность), kurioje skirdavo: multietninius arba kvazistruktūrinius, paprastai tik bendra valstybès raida bei politiniais-socialiniais-ekonominiais siekiais pagrịstus darinius (a), bendra etnine prigimtimi, kultūriniu identitetu, valstybingumo savimone išsiskiriančius darinius (b) ir etniniais savitumais pasižyminčias teritoriškai glaudžiai susijusias žmonių bendruomenes (c). Mègdžiojant anglosaksų tradiciją „naciją“ ir „tautą“ vadinti vienu vardu (nation), o lietuvių kalboje versti tai tik kaip „tautą“, prasidèjo šių sąvokų painiojimas ir visuotinis lingvistinis „tautinimas“. Būdinga, kad net toks visapusiškai geras ir esmę tiksliai nusakantis žodžių junginys - „Suvienytųjų nacijų organizacija" (SNO) - dabartinejje lietuviškoje vartosenoje (matyt, dèl politinių rusofobinių priežasčių) buvo pakeistas nevykusiu deriniu - ,jungtinès tautos" (JT), tarsi pripažįstant amerikiečių, australiečių ar sovietų tautas, apimančias atitinkamų valstybių teritorijoje gyvenančius žmones.

\section{TAUTOS INTERPRETACIJA LIETUVIŠKOJE LITERATŪROJE}

Jau tarpukario Lietuvos klasikinèje istoriografijoje susiformavo skirtingos tautos termino sampratos pradmenys (Kavaliauskas, Prunskyte, 2012). Vydūnas (Vydūnas, 1920) savo formuojamoje organiškos tautos sampratoje teigè, kad tauta turi ne tik sociume besireiškiančią empirinę būtį, bet ir transcendentinę (metafizinę), kurios pamatas yra nuolat veikiančios kūrybos galios, nubrěžiančios jai užduotis ir misiją. Todèl tauta yra ne kas kita, kaip organiškas visumos galių pasireiškimo vienetas, turintis kūną, gyvybę, psichiką, minčių bei dvasios pasaulius, kurie besipindami sudaro tautos charakterị, labiausiai pasireiškiantị moksle, mene ir doroje. A. Šapoka (1936) ir S. Šalkauskis (1992) tautos sampratą aiškina kaip žmonių bendriją, susietą bendra kalba, istoriniu likimu, papročiais, gyvenamaja teritorija ir suvokiančią savo bendrumą. M. Riomeris (1995) skiria du tautos tipus: tauta - populus, kaip socialinis junginys, tapatus valstybės narių visumai, kas apytikriai atitinka sovietmečiu mūsų kalboje ịtvirtintam nacijos terminui arba dabartinei politinei tautai, ir tauta - nationi, kai junginys skiriamas nacionaliniais požymiais. Nacionalinė tauta yra sudètingas kultūrinis ir mentalinis (psichinis) reiškinys, jo 
egzistavimą veikia įvairūs veiksniai, pavyzdžiui, pirminè etninè grupé, kalba, istorinès kultūros tradicijos, atsiminimai ir sąmoningas apsisprendimas. Dar kitoks požiūris išryškèja A. Maceinos teiktame (1934) tautos apibrèžime. Jo įsitikinimu, tautą sudaro trijų veiksnių išdavos: rase, istorinis likimas ir gyvenamoji gamtinè aplinka. Šiuo atveju rasè ir gamtinè aplinka suformuoja "gamtinę" tautą, o istorinis likimas sukuria tautas kaip kultūrinị vienetą. Taigi A. Maceina tautą vadina kultūros ir natūros sintezès rezultatu, kas priartina šią sampratą prie šiuolaikinio etnogeocenozès supratimo. Kiek vèliau A. Maceina (1939) tautą ịvardijo kaip organišką bendruomenę, jungiamą visą gyvenimą persunkiančiais vidiniais ryšiais, taip priartėdamas prie Vydūno pažiūrų.

Dabartinejje lietuviškoje literatūroje tebevyksta gana aktyvi diskusija tautos sampratos klausimais. Vienas žymiausių mūsų geopolitikų N. Statkus (2003; 2004) teigia, kad tauta net nèra kultūrinè ar istorinè sąvoka, o greičiau politinis fenomenas, kuriuo apibūdinamas etninès bendrijos politinis statusas tarptautineje sistemoje ir kurios nariai turi suverenaus ar autonominio politinio sprendimo teises. Tai jau ne kas kita, kaip akivaizdi tautos sąvokos konvergencija su nacijos samprata. Konstruktyvesniu laikytinas analitinis požiūris, reikalaujantis kalbant apie tauta išskirti tauta formuojančius veiksnius ir ją apibūdinančius požymius (Meškauskienè, 2000). Formuojančius arba organizuojančius veiksnius linkstama suprasti kaip pagrindinius, kurių dèka tauta gali palaikyti savo egzistavimą. Tautą apibūdinantys arba tipologiniai požymiai būtų tie, kurie pirmiausiai ir lengviausiai atskiria skirtingas tautas.

Ypatingi tauta formuojantys giminingi veiksniai lietuviškame kontekste būtų tautinè tapatybè (Kuolys, 2000; Aramavičiutè, 2008; Rimkus, 2013) ir tautinè savimoné (Jankauskas, 2007; Gineika, Letukienè, 2008; Trakšelys, 2008; Savoniakaitè, 2011; Pažèraitè, 2012), kurios kartais laikomos net svarbiausiu tautiškumo kriterijumi (Gineika, Letukiené, 2008). Vienu atveju tautinè tapatybé suprantama kaip geografiniu (teritoriniu), lingvistiniu ir kultūriniu bendrumu paremtas individo buvimas su ta pačia etnine grupe, ją laikant savo tauta (Aramavičiutè, 2008), o kitu atveju - tautinè tapatybè suprantama kaip žmogaus priklausomybẻ konkrečiai tautai, laikant tai natūralia pareiga (Kuolys, 2000). Aišku, tautinè tapatybè neatsiran- da savaime, ji natūraliai yra paveldima iš savo tèvų (Meškauskienė, 2000).

Aptariant pačią tauta kaip organizacinę visumą dabartinejje lietuviškoje literatūroje randame įvairių apibūdinimų - tai: etnokultūrinė visuma (Kuolys, 2000), istoriškai susidariusi žmonių bendruomenè (Bilkis ir kt., 2006), istorinis subjektas (Pažèraitè, 2012), etninè kultūriné žmonių bendruomenè (Gineika, Letukienè, 2008), žmonių bendruomenè (Ankudavičienè ir kt., 2003) ir pan. Tauta ìvardyti tik kaip žmonių bendruomenę yra tiesiog per platu. Juk žmonių bendruomenę gali sudaryti ir savitų kultūros bruožų, ir identiteto neturinti interesais susieta žmonių sankaupa. Tikslesnis būtų etnokultūrinis įvardijimas arba etninis kultūrinis žmonių bendruomenès suvokimas, tačiau tai labai koreliuotusi su tipologiniais tautos požymiais (bendra kultūra ir etninis bendrumas). Bene geriausias būtų istorinio subjekto predikatas, kuris atspindi tauta kaip per tam tikrą istorinị laikotarpi susidariusį erdvinị, vieningai funkcionuojantị, visuomenès pagrindu susiformavusị organizmą.

Prie kitų tautą formuojančių veiksnių lietuviškoje literatūroje kartais priskiriama etnopolitika (Trakšelys, 2008) ir solidarumas (Meškauskienè, 2000). Etnopolitika atspindi tautu (kaip ir genčių ar genčių sąjungų) tarpusavio sąveiką politinèje sistemoje bei politini tautos charakterị ir yra tautu naudojamos priemonès, padedančios kovoti su tauty tarpusavio asimiliavimu ar išnykimu. Vis dèlto straipsnio autoriai nemano, kad ją reikètų priskirti prie prigimtinių tautas formuojančių veiksnių - tai daugiau bendros politinès organizacijos sudètinè dalis. Pristatomai prigimtinių organizacinių veiksnių grupei taip pat nepriskirtinas ir solidarumo veiksnys, nes tautos formavimasis negali būti ribojamas žmonių pažiūromis ar vienybe paremtomis tautinemis nuostatomis. Galimos tiek maksimaliai solidarios (pvz., žydai), tiek ypač besiskaldančios (pvz., lietuviai) tautos. Šio veiksnio, kaip organizacinio, deklaravimas yra daugiau valdančiųjų arba iš Vakarų perimtos liberaliosios ideologijos atspindys, nes iš esmès jị būtų galima skirti tik prie antraeilių tipologinių tautos požymių.

Dabartinejje lietuviškoje literatūroje aptinkamas ištisas tipologinių tautos požymių kompleksas. Vienas iš dažniausiai minimų tokių požymių yra bendra kultūra (Mitrikas, 2000; Balčys, 2006; Bilkis ir kt., 2006; Jankauskas, 2007; Aramavičiute, 2008; Gineika, Letukienė, 2008; Trakšelys, 2008; 
Butkus, 2009; Kundrotas, 2009; Grigas, 2009; Meškauskienè, 2000; Pažèraité, 2012). Kalbant apie kultūrą reikia pabrèžti būtent tuos elementus, kurie labiausiai išskiria ją iš aplinkinių kultūrų (Grigas, 2009). Tokie skiriamieji kultūros elementai galètų būti tautinè apranga, meno dirbiniai, žodinis paveldas ir kt.

Dar vienas dažnai minimas svarbus tautos požymis - bendra kalba (Kuolys, 2000; Meškauskienè, 2000; Mitrikas, 2000; Ankudavičienè ir kt., 2003; Bilkis ir kt., 2006; Jankauskas, 2007; Aramavičiutè, 2008; Gineika, Letukienè, 2008; Butkus, 2009; Pažèraité, 2012). Kalbą, kaip pagrindinị tautą nusakantị požymí, išskiria nemaža dalis lietuvių autorių (Kuolys, 2000; Meškauskienė, 2000). Akivaizdu, kad, nuvykus ị svetimą kraštą, pirmas ispūdis apie to krašto gyventojus susidaro iš ju vartojamos kalbos.

Kiti dažnai ịvardijami tauta nusakantys požymiai būtų bendra teritorija (Kuolys, 2000; Mitrikas, 2000; Balčys, 2006; Bilkis ir kt., 2006; Jankauskas, 2007; Aramavičiutè, 2008; Gineika, Letukienè, 2008; Pažèraitè, 2012), tiksliau - tèvynè (Kuolys, 2000), su apytiksliu teritorijos apgyvendinimo centru (Jankauskas, 2007; Gineika, Letukienė, 2008) ir bendra istorine atmintimi (Meškauskiené, 2000; Mitrikas, 2000; Ankudavičienè ir kt., 2003; Bilkis ir kt. 2006; Jankauskas, 2007; Gineika, Letukienè, 2008; Butkus, 2009; Grigas, 2009). Istorinè atmintis laikoma viena iš pagrindinių tautos tvarumą palaikančių prielaidų (Grigas, 2009). Istorija yra ne tik mokytoja, bet ir patriotiškumo įkvèpeja. Juk žmonès, neišmanantys savo gimtosios istorijos, taip ir lieka vaikais, kurie gyvena šia diena. Net pati tauta suprantama kaip istorinis subjektas (Pažèraitè, 2012). Istorija, kaip ir pati laiko tèkmè, yra neatsiejama tautos pradžios ir pabaigos liudininkè.

Dabartinejje lietuviškoje literatūroje mažiau minimi tipologiniai tautos požymiai - tai etninis bendrumas (Balčys, 2006; Gineika, Letukienè, 2008), bendra kilmè (Mitrikas, 2000; Ankudavičienè, 2003; Bilkis ir kt., 2006) ir tautos vardynas (Aramavičiutè, 2008). Etninis bendrumas labiausiai pasireiškia formuojantis etnosui iš greta vieno ar kito esančių teritorinių darinių, kuriuos dažniausiai sieja kultūriniai ir lingvistiniai panašumai. Šis požymis išsiskiria dar tada, kai pradeda formuotis potencialūs teritoriniai centrai, tarpusavyje besidalinantys ịtakos sferomis, ir mažesnių teritorinių vienetų priklausymas konkrečiam centrui tampa akivaizdus. Etninis bendrumas galutinai susiformuoja kartu su pačiu etnosu, kai teritoriškai išsiskiria etninès sąungos. Net ir susiformavus tautai etnoso pagrindu, etninis bendrumas toliau išlieka kaip svarbus veiksnys, davęs pradžią pačiai tautai. Etninis bendrumas pabrèžia tautą kaip atskirą rūši, susiformavusią natūraliu pagrindu. Bendrą tautos kilmę galima suprasti kaip pačios tautos pradžiu pradžią, kuri dažnai lieka nepelnytai užmiršta. Požymių vardijimą užbaigia tautos vardynas: asmenvardžiai, vietovardžiai, jų grafinè išraiška, taip pat aplinkinių tautu duotos pravardès. Akivaizdu, kad iš žmonių vardų, pavardžių, miestų ir kaimų pavadinimų ar panašių dalykų jau galime suprasti, apie kokią teritoriją ir joje gyvenančią tauta yra kalbama.

Aptarus tauta formuojančius veiksnius ir ją apibūdinančius tipologinius požymius, galima pateikti toki lietuviškaja klasikine ir dabartine sociologine literatūra paremtą jos apibrèžimą: tauta - tai savo tapatybę identifikuojantis istorinis subjektas, pasižymintis bendra tèvyne, istorine atmintimi, kultūra, kalba, kilme, sąmoningu apsisprendimu bei savitu vardynu ir savivardžiu. Tai parodo šio termino giminingumą etnosui, kuris paprastai reiškia istoriškai susiformavusią, bendrų etninių, kultūrinių požymių (kilmè, kalba, teritorija, savimone, etnopsichologija, etnografiniai bruožai, tradicijos ir kt.) turinčią žmonių bendriją.

\section{TAUTOS INTERPRETACIJA DABARTINĖJE ANGLIŠKOJE LITERATŪROJE}

Šiame skyriuje galimas tautos apibrēžimas formuojamas remiantis dabartine angliška literatūra. Be abejo, tokio pakankamai sudètingo darinio kaip tauta apibrěžimas turètų būti atitinkamo sudètingumo (kompleksiškumo) ir apimti ne tik tai, kas gali nusakyti žemesnius nei tauta darinius (gentinius junginius) ar iš dalies pačią tauta, bet ir tai, kas pabrèžia pačią tautos sampratą. Angliškoje literatūroje skiriami: a) esminiai tautos bruožai, kurie nèra būdingi žemesniems etniniams dariniams ir b) bendriniai tauta apibūdinantys bruožai, kurie gali būti iš dalies būdingi žemesniems teritoriniams dariniams.

Labai svarbus esminis tautos bruožas - tautinè savimonè (self-consciousness). Akivaizdu, kad kartu gyvenantys žmonès anksčiau ar vèliau pradeda suprasti savo vientisą visuomeninị darinị, kaip ypatingą 
ir išsiskiriantị iš jị supančių aplinkinių teritorinių darinių. Tada ir atsiranda žmonių supratimas apie savo priklausomybę ne sau, ne kitam, bet tautai. Būtent, priklausomybė konkrečiai tautai reiškia kartu ir žmogaus pareigą likti ištikimam savo šaknims. Tautine tapatybę, kaip vieną iš pagrindinių bruožų, išskiria ne vienas anglakalbis autorius (Miller, 1997; Smith, 1999; Baycroft, Hewitson, 2006; Harris, 2009).

Kitas svarbus tautos bruožas, akcentuojamas angliškoje literatūroje, yra solidarumas (solidarity) (Baycroft, Hewitson, 2006; Mayhew, 2009; Reill, 2012). Žmonių tarpusavio vieningumą, kaip vieną iš svarbiausių bruožų kalbant apie tautas, dar $1882 \mathrm{~m}$. išskyrè vienas žinomiausių prancūzų filosofuc E. Renanas (Reill, 2012). Jo manymu, tauta yra politinis vienetas, paremtas bendra valia, rūpesčiu, auka ir bendra istorine atmintimi. Panašus požiūris vyravo ir to meto (XIX a. II pusè) Europoje, kurioje tauta buvo galima suprasti kaip organizuotą bendruomenę, susaistytą priesaika, užtikrinančią tautą sudarančių žmonių tarpusavio bendradarbiavimą ir socialinį teisingumą (Reill, 2012). Dar labiau solidaruma pabrèžè T. Baykroftas ir M. Džewitsonas. Jie teigè, kad tauta suprantama kaip puikiai išreikštas solidarumas (Baycraft, Hewitson, 2006). Aišku, kai tautiečiai vienas kitą vertina kaip brolius ar seseris, o ne kaip iš kažkur atvykusius svetimšalius, tada ir tautos samprata igauna pirminę prasmę.

Bendrinius tautos bruožus sudaro ištisas kompleksas jos požymių, kurie gali būti iš dalies aktualūs žemesniems teritoriniams dariniams, bet kartu išsamiau apibūdinantys ir pačią tautą. Vienas iš svarbių tautos bruožų - bendra kultūra (cultural integrity). Jis dominuoja daugumoje angliškų tautos apibrèžimų (Miller, 1997; Gilbert, 1998; Davison ir kt., 2001; Baycroft, Hewitson, 2006; Harris, 2009; Mayhew, 2009; Blyndur, Mann, 2010). Mažai tikètina, kad musulmonas tapatintų save su budistu ar panašiai. Taip pasaulyje skirtingų kultūrų pagrindu susiformavo atskiri regionai, kuriuose formuojasi atskiros ir savitos tautos. Aišku, viena iš svarbesnių kultūros dedamụjų nuo seniausių laikų buvo religija. Dabartiniu laiku stipreja ir kitų kultūrinių tradicijų išskyrimas.

Dar vienas svarbus tautos bruožas - etninè kilmè (ethnic origin), kuri tai pat dažnai minima ìvairių anglakalbių autorių (Miller, 1997; Gilbert, 1998; Smith, 1999; Harris, 2009; Mayhew, 2009).
Logiška, kad tautos, kaip etnogeniniai teritoriniai dariniai, savo pradineje stadijoje susiformuodavo iš gretimų, vienas šalia kito esančių, gentinių vienetų, kurie, be abejo, vienas kitam buvo gerokai artimesni, palyginti su toliau esančiomis teritorinèmis bendruomenèmis. Taip formuodavosi etninis bendrumas, dažniausiai nulemtas lingvistinių, teritorinių, kultūrinių ar istorinių priežasčių.

Tai pat neatskiriama tautos dalis yra jos istorija, kuri ją lydi (kaip ir kiekvieną žmogų) per visą jos egzistavimą. Nors individualios istorijos priskyrimas atskiroms tautoms yra akivaizdus, bet ją, kaip svarbų požymi (palyginus su ankščiau minètais), ivvardija mažiau autorių (Smith, 1999; Mayhew, 2009; Reill, 2012).

Kitas neatsiejamas tautos bruožas - teritorija, kurioje ji susiformavo ir vystosi. Teritorija egzistuoja tarsi savotiška tautos, kaip ir žmogaus, "gimtinë", vystymosi terpé, kurioje tauta igavo savo etninị turinị. Dèl ịvairių istorinių aplinkybių pasitaiko atvejų, kada tautos lokalizacija praeityje galejjo ir kisti (pvz., žydai), dèl ko, matyt, tik dalis šiuolaikinių anglakalbių autorių ją akcentuoja kaip privalomą esmini požymį (Mayhew, 2009; Blunden, Mann, 2010).

Dar vienas neatsiejamas tautos bruožas - jos vartojama kalba. Šis bruožas nėra individualus. Tą pačią kalbą gali vartoti kelios tautos (geriausias pavyzdys - anglakalbès šalys). Be to, ta pati kalba gali šiek tiek skirtis, pavyzdžiui, vienos kalbos skirtingos tarmès. Idomu tai, kad tautiškai heterogeniškose anglakalbėse šalyse kalba, kaip privalomas atributas, tautos apibrèžimuose ne visada išskiriama (Simpson, Speake, 2009; Blunden, Mann, 2010).

Pagaliau lieka bendras politinis (Gilbert, 1998; Davison ir kt., 2001; Bork, 2010), socialinis (Davison ir kt., 2001; Bjork, 2010) ir ekonominis (Gilbert, 1998; Davison ir kt., 2001) gyvenimas. Akivaizdu, kad tauta galime prilyginti vieningai funkcionuojančiam organizmui, todèl visos jos sritys (socialinè, ekonominè, politinè) tiesiog privalo veikti vieningai, ką būtų galima ịvardyti kaip sveikos tautos požymi. Nesunku suvokti, kad vieningumo minètose srityse stoka tauta veda prie visiško žlugimo. Pažymètina, kad tai asocijuojasi su jau minèta mūsų Vydūno (1920) organiškos tautos koncepcija.

Iki išbaigto tautos apibrèžimo pagal šiuolaikinę anglakalbę literatūrą trūksta tautos, kaip visumos, 
apibūdinimo. Pačios tautos pagrindas, tikètina, yra etnosas, kuris pasižymi savais bendriniais bruožais, o būtinieji bruožai etnosui suteikia pačią tautos prasmę. Taigi, tauta, kaip visuma, yra tam tikra etnoso atmaina, jai būdingas per tam tikrą laiką susiformavęs savo tapatybès suvokimas. Remiantis šia tautos samprata (pagal vokiškają angliškojo termino nation interpretaciją), galima pateikti anglakalbe literatūra paremtą tautos apibrèžimą, kuris teigia, kad tauta - tai savo tapatybę identifikuojanti solidari žmonių bendruomenè, pasižyminti bendra kultūra, etnine kilme, istorija, teritorija, kalba ir bendru socialiniu, ekonominiu bei politiniu gyvenimu.

Angliškoje literatūroje akcentuojamas tautinio solidarumo požymis neabejotinai yra jau minèto termino nation dviprasmiškumo, šiuo atveju - nacijos sąvokos perdangos atspindys, ko neturime aiškiau diferencijuotame lietuviškame kontekste.

Iš pateiktų galimų tautos sampratos apibrèžimų matome ir panašumų, ir skirtumų. Suprantama, kad abu apibrèžimai atspindi tik tendencijas interpretuojant šią sąvoką angliškoje ir lietuviškoje mokslinejje literatūroje. Straipsnio apimtis neleido peržiūrèti kitose šalyse, visų pirma Rusijoje ir Vokietijoje, vystomų savitu tautos sampratos versijų. Šiame straipsnyje pristatomu tautos versiju jokiu būdu negalima laikyti tobulomis ar visiškai išbaigtomis - pati tauta, kaip etninis politinis reiškinys, yra daugiabriaunis, dinamiškas, net su tam tikrais transcendentiniais elementais (istorine atmintis, istorinis likimas, psichologinè-emocinè struktūra ir pan.), todèl jo tiesiog neįmanoma sutalpinti i trumpą statišką sakinị.

\section{NACIJOS SAMPRATOS YPATUMAI}

Kai tauta susiformuoja, jos tolesnès raidos procesai nesustoja ir toliau gali vystytis i dar sudetingesni darini, vadinamaji nacija. Suprantama, kad tauta ir nacija nèra sinonimai, nes nacija yra aukštesnès pakopos visuomeninis darinys nei tauta, nors ir turi abi savokas perdengiančių požymių. Taigi, nacijos sąvoka turi būti apibūdinama ne tik tais bruožais, kurie būdingi tautos apibrežimui, bet ir tais, kurie netipiški tautos sampratai ir skiria pačią nacija nuo tautos.

Kalbant apie nacijos sąvoką literatūroje anglų kalba vèl tenka prisiminti žodžio nation reikšmę, bet ši sykị tapatinant jị su nacija, o ne su tauta, kaip darème ankščiau, interpretuodami anglakalbị tautos supratimą. Žodynų anglų kalba (Barber, 2004; Moore, 2004; Deverson, Kennedy, 2005; Bjork ir kt., 2010; Lindberg, 2008; Simpson, Speake, 2009; Lindberg, Stevenson, 2010; Stevenson, 2010; Waite, 2012 ir kt.) nation apibrèžimuose visur yra išskiriamas valstybingumas (nationhood), kuris šiame straipsnyje nebuvo priskirtas tautai. Todèl naciją, kaip nepriklausomą politinị subjektą, išskiria dalis užsienio autoriu (Barbara, 2002; Vizenor ir kt., 2012; Castree ir kt., 2013). Pati nacionaliné valstybè yra suprantama kaip teisine ir politinè organizacija, savotiškas erdvinis rèmas, kuriame gali formuotis sudètingesnè integruota kvazietninè struktūra - nacija.

Aišku, pati valstybė neatsiranda savaime, tam būtinas ir pačiu žmoniu noras. Tą norą geriausiai išreiškia nacionalizmas (nationalism), kuris suprantamas kaip ideologine valstybingumo siekio išraiška (Esposito, 2009). Pati nacionalizmo pradžia kartais siejama su JAV nepriklausomybès karu ir Didžiąja Prancūzijos revoliucija (Jaher, 2003), tačiau dažniausiai su tiesioginiu tautos noru atsiriboti nuo kaimynu ittakos (Mahan, Kim, 1997). Nacionalizmą net galima įvardyti kaip natūralią ir svarbiausią žmogaus kolektyvinio gyvenimo išraišką (Castree ir kt., 2013), kurios rezultatas - sava ir nepriklausoma valstybè.

Kitas svarbus veiksnys - nacionalinè tapatybė (national identity) (Lagasse, 1993; Vizenor ir kt., 2012), kurią galima suprasti kaip žmogaus priskyrimą konkrečiai nacijai su vienijančiais bendrais bruožais (Lagasse, 1993) arba tapatinimą su konkrečia nepriklausoma, ar iš dalies nepriklausoma (autonomija), politine organizacija (Vizenor ir kt., 2012). Aišku, jei žmogus nesuvokia savo nacionalinès tapatybès, nacionalizmas ir nacionalinè valstybè netenka prasmès. Kaip nacionalizmas sukuria valstybę, taip nacionalizmą savo ruožtu suformuoja nacionalinè tapatybè. Kai solidarumas ir nacionalumas pasiekia pakankamai aukštą lygit, paminèti bruožai tarpusavyje susimaišo ir taip suformuoja patriotiškumą (patriotism) (Doyle, Pamplona, 2006). Patriotiškumą net galima ìvardyti kaip aukščiausią nacijos politinę išraišką. Taigi, pažymèjus valstybingumą, nacionalizmą, nacionalinę tapatybę, patriotiškumą ir turint omenyje, kad nacijai būdingi ir tautos (kaip nacijos pagrindas) bruožai, jau galime pateikti anglakalbị nacijos sampratos variantą: nacija - tai valstybingumą 
formuojančio nacionalizmo, solidarumo ir patriotiškumo produktas, pasižymintis integruota nacionaline tapatybe, kalba, kultūra ir istorija. Palyginus su anksčiau aptartu tautos apibrèžimu, šiame nacijos apibrèžime sudètingo etnopolitinio darinio supratimas įsilieja ị valstybę, tautinè tapatybé virsta nacionaline (valstybine) tapatybe, tautiškumą pakeičia platesnis valstybinis integruotas nacionalizmas.

Dabar galime pereiti prie lietuviškos nacijos versijos. Priešingai nei apie tautos sampratą (be lygiaverčių nacijos ir tautos apibrèžimų), konkrečiau apie nacija Lietuvoje mažai rašyta. Turbūt svarbiausias nacija nusakantis bruožas čia irgi ịvardijamas valstybès buvimas (Daukšas, 2010; Kavaliauskas, Prunskytè, 2012). Apibūdinant naciją valstybė teikiama kaip šios idejjos rezultatas arba rèmai, kuriuose egzistuoja nacija.

Bandoma pabrěžti nacionalizmą (politiškai apibrèžtą tautiškumą), formuojantị pačią naciją (Kuzmickas, 2013), ir kurị galima įvardyti kaip nacijos varomąją jègą, paremtą individualia ideologija. Nepamirštamas ir pats smulkiausias nacijos elementas - pilietis, kurio pagrindu nacija galima ¿̇vardyti kaip valstybès piliečių visumą (Kavaliauskas, Prunskytė, 2012) arba piliečių politinès vienybès imperatyvą (Kuzmickas, 2013).

Jau buvo atkreiptas demesys (Kavaliauskas, Prunskyte, 2012), kad nacijos ir tautos sampratos problemos iki šiol neišsprende ir mūsų kalbiniai akademiniai leidiniai: Lietuvių kalbos žodynas (2012), Dabartinès lietuvių kalbos žodynas (2014) ir Tarptautinių žodžių žodynas (2004), kur nacijos ir tautos sąvokų išaiškinimai praktiškai nesiskiria, keičiasi nebent tik žodžių tvarka. Toliau pažengti nepavyko, nes minètų žodynų autorių buvo ignoruota neabejotinai pati svarbiausia nacijos sampratos formanta - bendra valstybe, kurioje tik ir gali formuotis toks polistruktūrinis kvazitetninis darinys. Visais kitais skirtingai varijuojamo bendrumo atvejais apibūdinamos tik įvairaus laipsnio monoetninès tautos.

Taigi, aptarus valstybingumo, nacionalizmo, piliečio sąvokas ir suvokiant, kad nacijai būdingi ir tautos bruožai, galime pateikti lietuvišką nacijos apibrèžimą: nacija - tai valstybinis, pilietinis, solidarus, integruojančio nacionalizmo polistruktūrinis kvazietninis darinys, istoriškai susiformavęs kalbos, teritorijos, socialinio-ekonominio gyvenimo, kultūros ir nacionalinès savimonès bendrumo pagrindu. Palyginti su prieš tai aptartu „angliškuoju“ nacijos apibrèžimu, šiame apibrèžime atsiranda žodžiai "pilietinis“ (pabrèžiantis piliečio sąvoką) ir "polistruktūrinis kvazietninis“ (pabrèžiantis tautų integracijos potencialą), tačiau nebeliko „patriotiškumo“.

Diskutuotina yra užsienio diasporų (tautos dalių, tautinių bendruomenių, gyvenančių ne savo istorinèje Tèvynèje) ittraukimo ì tautos ar nacijos sąvokas. Turbūt tai nevienareikšmis reiškinys, nors iš esmès (kaip rodo jų pačių apibrèžimas) tautinès diasporos neabejotinai priklauso tautai. Tačiau jei valstybe organizacinèmis institucijomis palaiko ryši su užsienio diasporomis suteikiamos pilietybès pagrindu, tas jau sudaro galimybę kalbèti ir apie transnacionalizmą, apjungiantị deteritorializuotą tautą ir nacionalinę valstybę i̇ vieną visumą (Daukšas, 2011; Castree ir kt., 2013) priklausant valstybei pilietybès pagrindu. Priskyrus diasporą nacijai, ši tampa lygiateise nacijos dalimi, kuria privalo rūpintis ir ginti motininè nacija.

Kaip ir tautos atveju abu pateikti nacijos apibrèžimai nèra tobuli ir ateityje juos neabejotinai teks koreguoti atsižvelgiant $\mathfrak{i}$ konkrečias visuomenès politinių teritorinių darinių raidos tendencijas bei faktus. Kaip vieną tokių bandymų galima laikyti šiuo metu Lietuvos geografų draugijos spaudai rengiamame Geografijos terminų žodyne (Geografijos terminų..., 2015) pateikiamą apibendrintą nacijos apibrèžimą: nacija - tai teritorinè, istoriškai susiformavusi, skirtingų rasių, tautų, kalbų, religiju atstovus suvienijusi, valstybiniu politiniu ir ekonominiu požiūriais organizuota, viena kalba kalbanti ir vieninga nacionaline savimone pasižyminti žmonių bendrija.

\section{APIBENDRINIMAS}

Tauta nuo seniausių laikų buvo suprantama kaip pagrindinis sudètingą teritoriškai organizuotą visuomeninị darinị nusakantis terminas. Tačiau nekonkretūs ar neišsamūs pačios tautos apibrèžimai, ypač iki XVIII a. pab., kai pradejo formuotis nation arba nacijos terminai, pagimde tautos ir nacijos sampratų problemiškumą. Terminologiniam aiškumui trukdè tai, kad abi šios sąvokos ilgą laiką buvo apibrèžiamos panašiai, nors ir tapatintos su pakankamai skirtingais teritoriniais dariniais.

Kita problemiškumo priežastis - nevienodas pačio termino nation suvokimas skirtingose to meto 
Europos valstybėse. Tai lèmé ịvairūs to meto revoliuciniai ir politiniai pokyčiai. Ypač neaiški buvo angliškoji nation versija, savyje talpinusi tautos ir nacijos terminus.

Kalbant apie tautą ar naciją dažniausiai yra minimi skiriamieji bruožai, kurie neabejotinai svarbùs abiems terminams, tačiau pati tautos ir nacijos esmé slypi šiomis sąvokomis ịvardijamas realijas formuojančiuose veiksniuose. Vien tik skiriamujjų bruožų nustatymas ir formuojančių veiksnių visiška ar daline diskriminacija kalbant apie tautos ar nacijos apibrèžimą ir lemia dabar egzistuojančią problemą.

Pabrèžtina, kad kalbant apie tauta ir nacija atitinkamai transformuojasi ir kai kurie jas formuojantys veiksniai. Taip tautinė tapatybè virsta nacionalumu, tautiškumas - patriotiškumu, didejja solidarumo svarba. Vis dèlto aiškiausiai ir konstruktyviausiai ribą tarp abiejų nagrinètų sąvokų nubrèžia visuomeniniame teritoriniame darinyje egzistuojantis valstybingumas ir pilietiškumas.

Suprantama, visi apibrèžimai atspindi tik tendencijas mokslinejje literatūroje interpretuojant sąvokas. Straipsnyje teikiamu tautos ir nacijos apibrèžimų versijų jokiu būdu negalima laikyti tobulomis ar visiškai išbaigtomis - tiek tauta, kaip etninis politinis reiškinys, tiek nacija, kaip valstybinis nacionalinis reiškinys, yra daugiabriauniai, dinamiški, net su tam tikrais transcendentiniais holistiniais elementais, todèl jų tiesiog neįmanoma pilnai sutalpinti ị trumpą statišką apibrèžimų forma.

Straipsnis atstovauja tik pradinei metodologinei daliai bendrame tautos ir nacijos tyrimų komplekse. Kaip perspektyvią tolesnių politinių geografinių tyrimų kryptị turètų sudaryti iki šiol dar neturimo, tačiau labai reikalingo, pasaulinio nacijų žemèlapio sudarymas, kuriame būtų pateiktas nacijų klasifikavimas pagal jų išsivystymo laipsnị ir šių dariniu teritorinè sklaida.

Gauta 20150302 Priimta 20150323

\section{LITERATŪRA}

1. Ambrazas S. 2006. Lietuvių kalbos būdvardžių su priesaga „ola" raida. Baltica. 16(1): 15-31.

2. Aramavičiutė V. 2008. Antano Maceinos tautinio auklèjimo idèjos globalizacijos kontekste. Acta paedagogica Vilnensia issn. 21(1): 30-40.
3. Baycroft T., Hewitson M. 2006. What is a Nation? Europe 1789-1914. New York: Oxford University Press.

4. Balčys J. 2006. Tautiškumo ir valstybiškumo idèjos dorovinis aspektas lietuviu filosofu darbuose 1910-1940. Problemos. 70(1): 18-30.

5. Barbara C. 2002. When is a nation? Comparing Lithuania and Georgia. Geopolitics. 7(2): 147-172.

6. Barber K. 2004. The Canadian Oxford Dictionary. 2 ed. Oxford: Oxford University Press.

7. Bjork R. E. 2010. The Oxford Dictionary of the Middle Ages. Oxford: Oxford University Press.

8. Blunden A., Mann T. 2010. Australian Law Dictionary. Oxford: Oxford University Press.

9. Butkus A. 2009. Nominacija ir identitetas: habilitacinis darbas. Kaunas: VDU.

10. Castree N., Kitchin R., Rogers A. 2013. A Dictionary of Human Geography. Oxford: Oxford University Press.

11. Cresswell J. 2010. The Oxford Dictionary of Word Origins. 2 ed. Oxford: Oxford University Press.

12. Dabartinés lietuvių kalbos žodynas. 2006. S. Keinys, L. Bilkis, J. Paulauskas, V. Vitkauskas (red. kolegija). Vilnius: Lietuviu kalbos institutas.

13. Dabartines lietuviu kalbos žodynas. 2014. http:// www.lki.lt/dlkz/ (žiūrèta 201404 22).

14. Daukšas D. 2010. Iššūkiai pilietybei ir etniškumui šiuolaikineje Lietuvoje: Lietuvos tautiniu mažumu ir lietuviškos migracijos atvejai: daktaro disertacija. Kaunas: VDU.

15. Daukšas D. 2011. Dominuojantis nacijos, teritorijos ir valstybès diskursas lietuviškoje 1988-1991 m. periodikoje. Liaudies kultūra. 5(140): 7-16.

16. Davison G., Hirst J., Macintyre S. 2001. The Oxford Companion to Australian History. Oxford: Oxford University Press.

17. Deverson T., Kennedy G. 2005. The New Zealand Oxford Dictionary. Oxford: Oxford University Press.

18. Doyle D. H., Pamplona M. A. 2006. Nationalism in the New World. Athens: University of Georgia Press.

19. Esposito J. L. 2009. The Oxford Encyclopedia of the Islamic World. Oxford: Oxford University Press.

20. Geografijos terminu žodynas. 2015. Lietuvos geografų draugija (rengiamas spaudai).

21. Gilbert P. 1998. The Philosophy of Nationalism. Boulder: Westview Press.

22. Gineika J., Letukienè N. 2008. Istorija. Politologija. Vilnius: Alma littera.

23. Grigas R. 2009. Lietuvos tautos paveldas - šalies tapatumo pagrindas. Iš: Bibliografija. 95-103.

24. Harris E. 2009. Nationalism: Theories and Cases. Edinburgh: Edinburgh University Press.

25. Iliustruotas enciklopedinis žinynas. 2003. N. Ankudavičiene ir kt. (sud.). Vilnius: Jotema.

26. Jaher F. C. 2003. The Jews and the Nation: Revolution, Emancipation, State Formation, and the Liberal Paradigm in America and France. Princeton: Princeton University Press. 
27. Jankauskas A. 2007. Politikos mokslu enciklopedinis žodynas.Vilnius: Vilniaus universiteto leidykla.

28. Jokantas K. 1995. Lotynų-lietuvių kalbu žodynas. Vilnius: Aidai.

29. Kavaliauskas P., Prunskyte J. 2012. Valstybingumo teritorinès raiškos optimizavimo problema (tautų apsisprendimo teisès kontekste). Geografijos metraštis. 45(1): 45-65.

30. Kundrotas M. 2009. Tauta amžiu kelyje: tautines pasaulèżiūros gairès ir tautinis judèjimas Lietuvoje. Vilnius: Vilniaus pedagoginio universiteto leidykla.

31. Kuolys D. 2000. Lietuvio ir Lietuvos sąvokos XVIXVII amžių lietuviškuose raštuose. Kn.: Kultūru sankirtos: skiriama dr. Ingès Lukšaités 60-mečiui. Vilnius: Diemedis. 157-170.

32. Kuzavinis K. 2007. Lotynu-lietuviu kalbu žodynas. Vilnius: Mokslo ir enciklopedijų leidybos institutas.

33. Kuzmickas B. J. 2013. Tautos samprata - paradigmu kaita. Socialiniu mokslu studijos. 5(4): 987-996.

34. Lagasse P. 1993. The Columbia Encyclopedia. 6th ed. New City: Columbia University Press.

35. Lietuviu kalbos žodynas. 2012. http://www.lkz.lt (žiūrèta 20140606 ).

36. Lietuvos etnologijos ir antropologijos enciklopedija. 2011. V. Savoniakaitè (sud.). Vilnius: LII leidykla.

37. Lindberg C. A. 2008. Pocket Oxford American Thesaurus. 2 ed. Oxford: Oxford University Press.

38. Lindberg C. A., Stevenson A. 2010. New Oxford American Dictionary. 3 ed. Oxford: Oxford University Press.

39. Maceina A. 1934. Tautinis auklejimas: disertacija. Kaunas.

40. Maceina A. 1939. Tauta ir Valstybè. Kaunas.

41. Mahan M. J., Kim M. R. 1997. The Morality of Nationalism. New York: Oxford University Press.

42. Mayhew S. 2009. A Dictionary of Geography. 4 ed. Oxford: Oxford University Press.

43. Meškauskienè E. 2000. „Nacionalizmo“, „tautiškumo“" „tautos" terminų samprata akademiniuose Lietuvos autorių darbuose. Kn.: Etniškumo studijos: teoriniai samprotavimai ir empiriniai tyrimai. Vilnius: Eugrimas. 14-22.

44. Mitrikas A. 2000. Etniškumo studijos: teoriniai samprotavimai ir empiriniai tyrimai: straipsnių rinkinys. Vilnius: Eugrimas. 7-13.
45. Moore B. 2004. Australian Oxford Dictionary. 2 ed. Oxford: Oxford University Press.

46. Miller D. 1997. On Nationality. Oxford: Clarendon Press.

47. Pažèraitė A. K. 2012. Termino ethnos reikšmių pokyčiai: nuo Biblijos vertimų iki naujųjų utopijų. Religija ir kultūra. 11(1): 32-62.

48. Reill D. K. 2012. Nationalists Who Feared the Nation: Adriatic Multi-nationalism in Habsburg Dalmatia, Trieste and Venice. Stanford: Stanford University Press.

49. Rimkus E. 2013. Individas, tauta ir visuomenè postmoderniame pasaulyje. Santalka: filosofija, komunikacija. 21(1): 65-79.

50. Riomeris M. 1995. Valstybe. Vilnius: Pradai.

51. Simpson J., Speake J. 2009. The Oxford Dictionary of Proverbs. 5 ed. Oxford: Oxford University Press.

52. Smith A. D. 1994. Nacionalizmas XX amžiuje. Vilnius: Pradai.

53. Smith A. D. 1999. Myths and Memories of the Nation. Oxford: Oxford University Press.

54. Statkus N. 2003. Etniškumas ir nacionalizmas. Vilnius: VU leidykla.

55. Statkus N. 2004. Tapatybès politika etniniams konfliktams reguliuoti. Vilnius: VU leidykla.

56. Stevenson A. 2010. Oxford Dictionary of English. 3 ed. Oxford: Oxford University Press.

57. Šapoka A. 1936. Lietuvos istorija. Kaunas: Švietimo ministerijos knygų leidimo komisija.

58. Šalkauskis S. 1992. Rinktiniai Raštai. Vilnius: Vaivorykštes.

59. Tarptautiniu žodžiu žodynas (3 leid.). 2004. Vilnius: Alma litera.

60. Trakšelis K. 2008. Etnopolitika ir ją sąlygojantys veiksniai. Filosofija. Sociologija. 19(2): 1-8.

61. Vizenor G., Doerfler J., Wilkins D. A. 2012. The White Earth Nation: Ratification of a Native Democratic Constitution. Lincoln: University of Nebraska Press.

62. Vydūnas. 1920. Tautos gyvata. Tilžè.

63. Waite M. 2012. Oxford Paperback Thesaurus. 4 ed. Oxford: Oxford University Press. 
Paulius Kavaliauskas, Mindaugas Jakutis

\section{PROBLEM OF DEFINITION OF} THE NATIONALITY AND THE NATION

\section{Sum mary}

The article focuses on the concepts of nationality and nation. The authors present an analysis of the terms of nationality (people) and nation in the Lithuanian and English. Interpretation of the nation and nationality is one of the most significant problems of political geography, history, ethnology and others.

Nationality (people) is traditionally identified as a large group of people who share a common language, culture, history and territory. According to the authors of the article, the nationality is formed by identity, nationhood, homeland, language, culture, historical memory, ethnic basis, common origin, common list of acceptable names, often common social, economic and political life as well as solidarity. The more complex structure of society is a nation. The word nation came to English from the old French word nacion, which in turn originates from the Latin word natio literally meaning that which has been born. The nation began to emerge in the late 18th century as the leading form of government and social organization. The nation was traced to the French Revolution and ideas deriving from 18 th century French philosophers. The nations are a modern quasiethnic phenomenon arising from the primary people. The main signs of nation are identified as integrated statehood, but according to the authors of the article, the nation is formed by citizenship, nationalism, self-consciousness and solidarity.
As for the sense of nationality or the nation, the most frequently mentioned are the distinctive features that are clearly important to the nationality or the nation, but the nationality's and the nation's essence lies in the factors that shape the realities identified by these notions. It is one of the distinctive features of exclusion and the factors shaping the full or partial discrimination with regard to the definition of a nationality or a nation, and is determined by the current problematic existence. It should be noted that some of factors forming the people and nation are transformed accordingly. It turns national identity into a nationality and nationalism into a patriotism, respectively, also increasing the importance of solidarity. However, the statehood and citizenship clearly and constructively examine the boundary between the two concepts.

It is understood that all of the definitions only reflect trends in the interpretation of the concept of scientific literature. The definition versions of the nationality and the nation given in the article should never be perfect or fully completed - both ethnic people as a political phenomenon and nation state as a national phenomenon are multifaceted, dynamic, even with some transcendent elements, therefore they simply cannot be fully included in a short static form of definitions.

This article represents only the initial part of the nationality's and nation's methodological research complex. As a viable political geographical direction of research in this problematique should be global mapping of nations, not yet available, but very necessary, including a classification of nations according to their development and distribution of these compounds.

Key words: nationality, people, nation, self-consciousness, nationalism, solidarity, state 